\title{
Distribution and Prevalence of Dermatophytes in Semi-Arid Region of India
}

\author{
Vishnu Sharma ${ }^{1 *}$, Tarun Kumar Kumawat ${ }^{1}$, Anima Sharma ${ }^{1}$, Ruchi Seth ${ }^{1}$, \\ Subhash Chandra ${ }^{2}$ \\ ${ }^{1}$ Department of Biotechnology, JECRC University, Jaipur, India \\ ${ }^{2}$ Vardhaman Mahaveer Open University, Kota, India \\ Email: sharmaanima6@gmail.com
}

Received 20 January 2015; accepted 8 February 2015; published 11 February 2015

Copyright (C) 2015 by authors and Scientific Research Publishing Inc.

This work is licensed under the Creative Commons Attribution International License (CC BY). http://creativecommons.org/licenses/by/4.0/

\begin{abstract}
Earth has been documented as a natural territory for fungi which cover individual kingdom with evolution. In subsequently vertebrates developed keratin which was a part of life as a structural aspect. Few moulds have skilled to digest keratin and crop up from soil and wastewater habitats. They take part as a keratinolytic agent in the purification of $\alpha$-keratins with an incidence of disulphide and hydrogen bonds which are improperly biodegradable. The best moulds genera to decay of keratin are Microsporum, Trichophyton and Epidermophyton. The presences of these genera are open health issues in developing countries where they cause the mortal mycotic contagion. The reason behind this is perceived to be the poor hygienic environment and socioeconomic behaviour among people. The present review is a compilation of updated information concerning the nature of these keratinolytic moulds and abundances of most contributed developing countries including India.
\end{abstract}

\section{Keywords}

Moulds, Keratinophytes, Dermatophytes, Keratinase, Mycoses

\section{Introduction}

Soil has long been recognized as a natural habitat for certain fungi [1]. They differ from plants in the absence of chlorophyll and differ from bacteria in the presence of cell walls that contain either cellulose or chitin [2]. The forest, farmyard, park soils, as well as sediments of the rivers and oceans containing humus and organic material are the best candidate for growth of keratinolytic and saprophytic fungi. More than 100 species of fungi are gen-

*Corresponding author.

How to cite this paper: Sharma, V., Kumawat, T.K., Sharma, A., Seth, R. and Chandra, S. (2015) Distribution and Prevalence of Dermatophytes in Semi-Arid Region of India. Advances in Microbiology, 5, 93-106.

http://dx.doi.org/10.4236/aim.2015.52010 
erally recognized as a pathogen for man found in soil [3]. Diseases caused by fungi, or Mycoses, can be clinically classified as superficial, deep, or systemic. Dermatophytes are the most important microorganisms, which cause superficial mycosis, and the lesions are characterized by circular disposition, desquamation, alopecia and erythema of the edges [4]-[6]. The dermatophytes have the capacity to invade keratinized tissue (skin, hair and nails) of humans and other animals to produce an infection, dermatophytosis, commonly referred to as ringworm [7] [8]. Dermatophytes are mycelial and keratinophilic fungi of the mold group, originally saprobial, but have adapted themselves to animal and human parasitism through evolution.

The Mycoses are caused by approximately 20 fungi, including dermatophytes, yeasts and non dermatophytes having the ability of parasitizing keratin rich tissues, which produce dermal inflammatory response and intense itching in addition to a cosmetically poor appearance [9]. The Mycoses caused by fungal infections of the skin and nails are widespread and the most numerous group amongst all Mycoses. During the last decades, mycotic infections are increased to more than $20 \%$ - 25\% of the world's population. Their etiological agents and predominating anatomical infection patterns vary with geographical location and environmental and cultural factors [10]. Such fungi grow at surface temperatures of $25^{\circ} \mathrm{C}-28^{\circ} \mathrm{C}$ with warm and humid conditions which is supported for infection on human skin. Infections by fungi are relatively common in tropical countries due to wearing of dirty and pungent clothing, low socioeconomic status, crowded living conditions, superficial skin infections, a low tendency to self limitation and poor medical care help to increase the epidemic spread of skin Mycoses. Also, booming tourism, international sports activities and increasing migration are responsible for disseminating an imported fungal group of Mycoses [11] [12].

Fungi have been categorized like an individual kingdom ever since the 1960s [13]. They embrace to yeast and moulds which are diverse in morphological and physiological appearance. They may populate sexually, asexually or both. These fungi are classified accordingly on the basis of stages in life cycle, the anamorphic and the telomorphic states [5] [14]. The anamorph is the state where asexual or somatic reproduction occurs and has a distinct morphology, while on the other hand, teleomorph is the sexually reproductive (perfect) state, morphologically differentiated from the anamorph [15]. Asexual reproduction is perceived mostly in clinically encountered fungi. In Dermatophytic fungi, some species of Microsporum and Trichophyton genera potentially produced perfect stage of fungi as the ascomata with asci and ascospores through sexually reproduction [16]. This typical species are considered as teleomorphs and genus Arthroderma by Berkeley, 1860 with the discovery of $A$. curreyi [14]. According to them, principal species in Microsporum are known as Nannizzia while Trichophyton species are considered as Arthroderma, respectively [5] [17]. The perfect states have peridium of freely combine, thin-walled, light colored hyphae, which is an attribute of the Arthrodermataceae. Genus Nannizzia has thick-walled, aseptate, hyaline cells with one or more symmetrical constrictions [18].

According to Botanical taxonomy, the fungi are divided into four major divisions: Zygomycota, Ascomycota, Basidiomycota and Deuteromycota. Out of these, Deuteromycota is the most important group which has abundance account of pathogenic fungi. These fungi have septate hyphae and reproduce asexually by producing conidia [19]. From all pathogenic fungi, few have ability to penetrate the natural keratin and play a role as the keratinolytic agent. Emmons, (1934) was the first individual who sited to dermatophytes into three anamorphic (asexual, imperfect) genera, Epidermophyton, Microsporum, and Trichophyton at Hyphomycetes class of Deuteromycota phylum [20] [21]. These organisms are pathogenic members of the keratinophilic (keratin digesting) soil fungi. Few species of these genera also have the capability of reproducing sexually similar as Teleomorphic genus Arthroderma of the Ascomycota phylum [22]. This classification was updated with new species by several reviewers [5] [23]. On the basis of anamorphic morphology, two species in Epidermophyton, approximately 18 species in Microsporum and 25 species in Trichophyton are considered as members of these genera [24] [25]. The main features distinguishing the three dermatophytic genera are:

\subsection{Epidermophyton}

The Epidermophyton genus was firstly established by Sabouraud in 1910 with the invention of species Epidermophyton rubrum (Epidermophyton interdigitale-Kanfmam Wolf). These fungi have the capability to invade the epidermis but also have rare possibility against the hair. So, according to the new classification, this species are placed into Trichophyton genera named as Trichophyton rubrum [26]. Another species is Epidermophyton floccosum [14] [20] [25]. This one is entirely an Anthropophilic fungus which is the cause of a common human disease known as Tenia [27]. The causing ability of these genera is known as epidermophytosis. Epidermophyton is recognized by the existence of massive conidia which have thin walled and clustered branches [28]. The thick- 
ness of the cell wall and shape varies depending on the species. Microconidia have Pyriform, about 2 - $3 \mu \mathrm{m}$ [29].

\subsection{Trichophyton}

Trichophyton genus was identified by Malmsten in 1845 with the discovery of species T. tonsurans [26]. This genus produces smooth walled macroconidia and microconidia. Macroconidia have thin walled and cigar-shaped. Microconidia can be pyriform about 2 - $3 \mu \mathrm{m}$ or irregular in form [25]. Members of the genus Trichophyton are the common agents of dermatophytosis [26]. They are especially significant in onychomycosis, but also invade the skin and hair, causing infection associated with substantial morbidity [30].

\subsection{Microsporum}

In 1843, Gruby was first named who identified Microsporum with the discovery of M. audouinii. The microscopically Microsporum fungus was confirmed at USA in 1956 [26]. The genus reproduces both micro- and macroconidia. Macroconidia are multiseptate, with thin or thick echinulate cell wall, spindle shaped and may be numerous or scarce [25] [27]. Causing by Microsporum is known as microsporosis, usually produces a single inflammatory skin or scalp lesion [31].

\section{Classification Based on Natural Habitat}

Dermatophytes are classified into three habitual species as Anthropophilic, Zoophilic, and Geophilic species in an environment [12] [32] [33]. Their habitat depends on the survival host as human, animals and soil [34] [35]. They show diversity in the disease causing host range.

\subsection{Anthropophilic}

The Anthropophilic fungi are more prevalent among urban populations, principally in developed countries. In today's modern life, wearing slim shoes is in fashion which sustains warm humidity favourable for the growth of these fungi [10] [36] [37]. These typical dermatophytes are aggressive against human being's keratinized epidermis as precedence [13] [38]. They have rare occurrence of causing Tinea in animals [35]. In addition, their occurrence is superior in population with poor socioeconomic status. They spread direct or indirect commonly in schools, barracks, prisons through flooring, clothing, linens, furniture, barber shop instruments [13] [39] [40]. E. floccosum and T. rubrum, both pathogenic species are these customary fungi which lead to Tinea [5] [41] [42]. In Microsporum genera, essentially M. audouinii, M. langeroni, M. rivalieri and M. ferrugineum, M. langeroni have been categorized [14].

\subsection{Zoophilic}

These dermatogens habitually attack simply on the animal keratin substratum. This is their site of communication with human beings as host [43] [44]. The major reservoirs of these fungi are pets, farm animals, or wild animals [45]. Mainly dairy farming workers and children are at hazardous stage, which are in regular contact with farm animals, as well as wild animals [12] [46]. Pathogenic spores are hardly active as saprophytes but endure in a resting position on infected resources of an animal foundation [47]. In zoophilic species, mainly $M$. canis, T. verrucosum, T. mentagrophytes, A. vanbreuseghemii, A. benhamiae are widespread representatives which cause the mycosis disease in animals as well as human infection [48] [49].

\subsection{Geophiles}

These saprophytic dermatophytes are soil habitual fungi which disgrace to keratin as crude essence in nature [47]. These are pathogenic against human as well as animals [24] [25]. The presence of these typical dermatogens in nature is infected by natural factors as soil $\mathrm{pH}$, temperature, humidity, environmental light, climate, chemical composition and amount of organic material in the soil [14] [50]. This group mainly consists of following members-M. gypseum, T. ajelloi, T. terrestre, K. ajelloi and M. fulyum.

\section{Keratinase-Chemical Armory of Dermatophytes}

Keratinase is a proteolytic enzyme involved in the crumbling of keratin [51]. Keratin is extremely strong pro- 
teins which have elite properties as well as inflexible and hard [52]. Keratin has two key shapes, alpha-keratin and beta-keratin. Alpha-keratin is established in humans and other mammals while beta-keratin is present in birds and reptiles [1]. Few organisms are proficient to digest it and arise from soil and wastewater habitats which participate as a keratinolytic factor in decaying $\alpha$-keratins with an incidence of disulphide and hydrogen bonds which are inadequately biodegradable [53]. The molecular mass of the keratinase enzymes ranges from $20 \mathrm{kDa}$ to $60 \mathrm{kDa}$ [54]. Certain strains of Microsporum and Trichophyton accumulate enzymes that dissolve the keratin and related fibrous proteins in hair, nails, skin, claws, feather, beak and hooves [55]. The extracellular keratinase produced by Trichophyton have 18 amino acids as alanine, aspartic acid, cysteine, glutamic acid, lysine, histidine, isoleucine, leucine, lysine, methionine, phenylalanine, proline, serine, threonine, tryptophan, tyrosine, and valine [56]-[58].

In primary infection of mycosis, arthroconidias adhere to keratinized surface. During epidermal surface infection, sparse fibrils make the relationship between fungal arthroconidia to keratinocytes. Even as inside skin level infection, novel produced arthroconidia illustrate thin and short appendices covering their whole shell. These then start to penetrate a larger contact area for greater relationship establishment between conidia and skin tissue [59] [60]. Adhesion of dermatophytes, release multiple serine-subtilisins and metallo-endoproteases (fungalysins) takes place, universally known as keratinases [61]. Clinically dermatophytes show diversity in substrate preference and invading to the stratum corneum of the skin, hair and nail [62]. After invading to skin by dematophytes, fungal metabolic products disperse by malphigian stratum to derive Erythema and Pruritus [63].

Contagious infection concerning the skin and epidermal surfaces are perilous on the planet, especially in children due to lack of hygienic environment and education [64]. An essential group of these pathogens is fungi [65] [66]. Fungi are pathologically separated into two extensive groups by Clayton and Midgley in 1989. First are the dermatophytes, which have a natural group of morphologically and physiologically allied molds. They are usually causative agent of the disease ringworm or tinea [67] [68]. Another one is a miscellaneous group of distinct filamentous fungi which are known as saprophytes. These fungi can generate a variety of clinical infections of skin, hair and nails as Pityriasis versicolor, Erythrasma and Trichomycosis axillaris [40] [43] [69]. Pathogenic fungi are divided into four groups as:

\subsection{Superficial}

Superficial Mycoses is limited to the stratum corneum of the membrane and hair [59]. Essentially, Infection has induced no inflammation. The contagion is universally harassing the skin of youth people, particularly the chest, back, and upper and lowe limbs of the body [64] [70]. Infection is encouraged by warm, humid environment and pitiable hygiene conditions all over the tropical and temperate regions of the earth [71]. In the superficial fungal contagion, each one dermatophytic mould constructs abundant or unusual characteristic pattern which is assumed as the causal agents. Superficial fungal infections are divided into 3 broad classes' as [72].

\subsubsection{Dermatophytosis}

The infections occur most only on dead Keratin at the top layer of the skin, hair and nails [73]. For example, Tinea barbae infects to the bearded area of the face, whereas Tinea pedis infects the foot [74]. The dermatophytes are mainly covered with infections to a single part of the body. Tinea capitis presents a significant endemic problem mainly in school children in the world [75]. The disease arises with settling separately on the skin, hairs, and nails in living beings [76] [77]. Tinea is the allusion of mycosis which presents as a considerable widespread problem generally in school children [75]. Among all Tinea implement, Tinea pedis is a universal infection, monitored in one in five adults. Tinea cruris cause crotch itch, crotch rot, eczema marginatum, gym itch, jock itch, jock rot. According to review of diseases of the foot 2003, 16 European countries have onychomycosis, as most frequent fungal infection in prevalence at $27 \%$ by Tinea unguium. Tinea nigra Disease also recognized as "Tinea nigra palmaris or plantaris is present as dark brown to black effortless patches on the palms of the hands and the soles of the feet” [78]-[83]. Dandruff (Pityriasis capitis) caused by Pityriasis ovale is another superficial dermatophytosis. This is a common chronic scalp condition marked by itching and flaking of the skin on the scalp [84]. The disease is commonly caused in billions immunocompromised persons by dermatophytes, yeast and non-dermatophytes agents [85].

\subsubsection{Tinea Versicolor}

This unique, superficial mycosis is a class of hygienic infection in adult beings. The characteristic symptom of 
infection is skin depigmentation. The humid position is exterior of the body containing sebaceous glands at the upper trunk, neck \& arms [64] [86].

\subsubsection{Cutaneous Candidiasis}

This classic mycosis is a type of skin infection generally caused by C. albicans [72] [87]-[89]. Infection occurs usually in the presence of warm, moist, and creased environmental areas such as the inguinal areas. Candida albicans is the innate Denizen of the mucous membranes of the genital, alimentary and upper respiratory tract of the host [90] [91]. The infection is located at the oropharynx, vagina and skin part of beings. Oropharyngeal and vulvo vaginal infections are usually recognized as thrush in women [92].

\subsection{Subcutaneous}

The subcutaneous Mycoses are infected through saprophytic fungi in nature [66] [93]. Infections are less aggressive than superficial contagion. Diseases are considered by a diverse group of infection that immediately gets dispersed into the keratinized dermis and tissue with presence of wounds [94] [95]. These invasive infections affect immune suppressed and transplanted patients also. The disease usually spreads gradually to next tissue and finally to the lymphatic [96]. Subcutaneous infections exist deeply amid in rural area's individuals [68]. Infections are restricted to the tropical and subtropical regions but Sporotrichosis are ubiquitous in the moderate region [97]. The common causes are Sporotrichosis, Chromoblastomycosis, Eumycotic Mycetoma and Hyalohyphomycosis [70].

\subsection{Systemic Mycosis}

The pathological fungi have a symbiotic parasitic association with lead infection resulting in establishment of disease in the host [98] [99]. The systemic infections are established in internal organs with entry through lungs, gastrointestinal tract and via intravenous routes [100]. The pathogenic agents of systemic mycosis are primary pathogenic fungi and opportunistic fungi. Primary Pathogenic Fungi are infected in pulmonary's basal and hilar division through respiratory path. During preliminary infection pathogens attack the lungs and then spread through various organelle division of the body. The primary infection includes Histoplasmosis, Blastomycosis, Coccidiomycosis and Paracoccidiomycosis [99] [101]. While opportunistic mycosis infections are caused by non pathogenic fungi with inherent virulence in immune-competent human host [102]. The causing morbidity increased in emergence of AIDS and cancer and post transplantation chemotherapy with more aggressiveness [103]. They cause infections through opportunistic fungi like Aspergillosis, Candidosis, Cryptococcosis [91] [99]. Other systemic infective agents are such as Trichosporon, Fusarium or Penicillium, which are non pathogenic fungi.

\section{Ecological Status of Dermatophytes}

Superficial infections are an open health issue in developing countries. Dermatophytes are proteolytic employer for the humiliation of keratin [51]. Few organisms are proficient to break it and arise from soil and wastewater habitats which participate as a keratinolytic factor in decaying $\alpha$-keratins [53]. Several analytical researches have contributed work on the dermatophytic fungi around the earth [104] [105]. The superficial Mycoses infection was identified from 1845-1987. The outcomes were positive around $62.19 \%$ cases through direct KOH mounts [106]. The more popular keratinolytic fungi are incorporated with two bio-safety altitude as: BSL-1 and BSL-2. The BSL-2 fungi are actual dermatophytes posing a higher risk to man than the BSL-1 [107]. A Study was carried out to get information on the occurrence of fungi liable for superficial Mycoses in the region of Tripoli, Libya [108]. The outlets were having the Dermatophytes as Malassezia furfur and Candida albicans. Again In Libya, the prevalence of superficial mycosis has been studied [109]. The study was based on 2224 cases isolated from Dermatology Clinic at Tripoli Medical Center. And they founded presence of Tinea corporis in abundance through Trichophyton violaceum, Trichophyton rubrum and Microsporum canis. In Nigeria, a contribution on the prevalence of dermatophytosis and associated non-dermatophytes were carried out among Islamiyya school children of ages 5 - 13 years old [110]. The study, found the presence of disease up to $91 \%$ in children respectively. The majority infection is affected by $M$. ferrugineum upto $15.4 \%$. The etiological agents have been isolated from The Gaza country which held ability to cause cutaneous mycosis. They detected the big prevalence of Tinea capitis, Tinea corporis and Tinea unguium infections respectively [69]. In Saudi Arabian's King Saud 
University, keratinolytic geophilic fungi are screened by a mycological team. There identify eleven genera and 19 species. From that Chrysosporium indicum (33.75\%) was the most available species [111]. About Korea, poultry farms are the biggest source for dermatophytes. These sources have huge amount of Aspergillus species [112]. Once again examined the hedgehogs in exotic pets in Korea and by then a 15 year old girl had been developed with Tinea manuum. The basic agent for that was Trichophyton mentagrophytes var. erinacei; a zoophilic fungus isolated [113].

In Mexico and Nezahualcoyotl City, the keratinophilic agents were isolated from pets. And they comparatively observed the presence in cat (67\%) and dogs (45\%) which represent the risk in contact persons [114]. The superficial fungal spores in socioeconomic persons were observed about $46.6 \%$ positive at AL-Yarmook Teaching Hospital containing abundance of Pityriases versicolor [85].

In Bangladesh, reports suggested the increment in the clinical spectrum of disseminated fungal infections and malignancy. And they observed in the presence of deep Mycoses as Histoplasmosis, Blastomycosis, Mucormycosis and Pulmonary aspergilloma [115]. Once more, two more mycologists surveyed the dermatophytic infections and observed the highest prevalence of Tinea corporis, T. Pedis, T. capitis, and T. unguium in city. For these all major etiological agents were Trichophyton and Microsporum, Epidermophyton [116].

In Iran, a study had been conducted on onychomycosis and Tinea pedis caused by several dermatophytes. The outlets of the study confirmed the prevalence rate of both infections in Iran [117]. In Ahvaz, southwest part of Iran, especially in Ahvaz assessed the frequency of dermatophytic infection. Here researcher reported about the species T. mentagrophytes, $T$. verrucosum, $T$. schoenleinii and M. gypseum from this study. All these species are potentially pathogenic fungi [118]. Again north Iran's Gorgan region have a profusion of dermatophytosis which was evaluated. And this region had the T. rubrum and E. floccosum species as etiological agent [119]. In a comprehensive study of cattle dermatophytosis in Iran, firstly studied by Ghahfarokhi who discovered two invectives as T. verrucosum and T. mentagrophytes [120]. In Pak history, two different mycological researching teams appraised the dermatophytes at Sindh state, Karachi and Liaquat University of Medical and Health Sciences, Jamshoro where they identified the 23 species of keratinolytic fungi which have hazardous planet against Pakistanis [121] [122].

India, the developing country has four climates namely tropical wet, tropical dry, subtropical humid and Montane amongst the whole planet [123]. These climates perform to gain and sustain superficial Mycoses in human which is a public health problem [124]. The Indian subcontinent and close areas have a large number of ringworm infections throughout Delhi, Burla, Bangalore, Calcutta, Poona, Hyderabad, Lucknow, Jaipur, Madras citizens [125]. Several Indian mycologists have been reviewed and reported the mycosis in India [12] [126]. In the northern region of India, the presence of Onychomycosis was evaluated which is a chronic fungal infection of nails. In this investigation T. mentagrophyte, T. rubrum and C. albicans is a key agent for nail onychomycosis [127]. In Himachal Pradesh, the occurrence of dermatophytes was examined in hilly areas and achieved about eleven species from five genera. Chrysosporium queenslandicum (25\%) and C. tropicum (19\%) have a key presence in H. P. [128]. The Punjab region, inspected the infection of Tinea capitis among children of Ferozepur. Here infection of Trichophyton violaceum observed specially up to 65\% clinically [129]. In M. P. the dermatophytes from humankind surface in Jabalpur have been isolated. The isolated genus was Fusarium, Curvularia, Fumigatus, Aspergillus and Mucor. All these have profusion in cellular protease production [130].

The north east region of India as Jharkhand has around 28\% tribal communisms with contacting through piggeries and pork habitats. In Ranchi, A. niger, F. oxysporum, P. chrysogenum, T. harzianum, T. reesei and A. alternata that are important keratinolytic fungi were isolated [131]. In eastern India, Kolkata witnessed a study of prevalence of Tinea capitis conducted among urban school children. The common infection was observed as dull gray patches [132]. The increased level of relative humidity shows excellent growth. The bases of it, in the south of India contain large parameter for infection of dermatophytes due to humid nature. Various temperature systems (as $0^{\circ} \mathrm{C}-50^{\circ} \mathrm{C}$ ) and relative humidity (as $11.05 \%$ - 95.00\%) were studied to evaluate the growth and sporulation of T. mentagrophytes, T. rubrum, M. canis and M. gypseum. Study of the occurrence and causative agents (fungus) of dermatophytosis was conducted in the Dermatology Section of Bharat Heavy Electrical Limited Hospital and Annal Gandhi Memorial Government Hospital, Tiruchirppalli, Tamilnadu, India [133]. With the sequence itself, Andhara Pradesh, recognized the Gulbarga district's humid environment for dermatophytes. And they observed clinical aetiological agents in great amount as T. mentagrophytes, M. gypseum, T. tonsurans, E. floccosum, M. audouinii and T. violaceum [134]. In Karnataka, estimated the clinical mycological status of Tinea capitis among children of urban population and the occurrence status of dermatophytes was $43 \%$ and 
common agent was T. rubrum [135]. Similarly, Madhya Pradesh was surveyed in 1986-1987, which reported about presence of T. rubrum (64.5\%), T. mentagrophytes (5.37\%), T. violaceum, E. flocceum (18.12\%), M. gypseum (7.52\%) and M. nanum [136].

The western regions of India have Thar Desert which plays a crucial role to attract moisture. By which the nature of region is dry tropical and subtropical. In this regard, the presence of dermatophytes in animals and firstly reported for Dermatophilus congolensis as a cause of dermatitis in humans, horse and antelope in College of Veterinary Science, Anand in Gujarat [137]. Again Baroda, observed 60.38\% positive infection of dermatophytosis among Guajarati's population. T. rubrum was the main agent for Tinea cruris [124]. In the sequence, once again study is conducted on the frequency of superficial infection in Tertiary Care Hospital, Ahmadabad. They're funded enormous amount of Tinea corporis infection caused by $T$. mentagrophytes in male than female up to $52.78 \%$ [138]. Mumbai has a busy life in the India. In Mumbai, reports on the occurrence of dermatophytes in five major public parks were shown. These parks enclosed eleven species as Arthrographis kalrae, Auxarthron conjugatum, Chrysosporium indicum, C. queenslandicum, C. zonatum, Gymnascella dankaliensis, G. hyalinospora, Microsporum gypseum, Myriodontium keratinophilum, Trichophyton mentagrophytes and Uncinocarpus reesii [139].

Rajasthan is the largest state, located in the northwest side of the Republic of India. Rajasthan is divided into 33 districts and seven divisions. It comprises most of the area of the large, inhospitable Thar Desert. Rajasthan covers $10.4 \%$ of India, an area of 342,239 square kilometers [140]. Jaipur is the capital and the largest city of the state. Temperatures can exceed $45^{\circ} \mathrm{C}$ in the summer months and drop below freezing in the winter. In Rajasthan three major districts are reviewed for dermatophytes by several mycologists [141]. The western part of Rajasthan, have a great amount of the Mycoses infections. In Jodhpur, the Sun City has been evaluated for the presence of dermatophytoses in the ruler hospital "Mathuradas Mathur Hospital” [142]. In South east part of Rajasthan, Kota districts have an atmospheric humid climate which is suitable for overgrowth of dermatophytes. In Kota, walk around in the presence of onychomycosis in citizens and observed 50.9\% attendance of Tricophyton species including T. tonsurans, T. rubrum and T. mentagrophytes [143]. In the south western area of Rajasthan, examined the skin disorders in the child's community and resulted out up to $40.60 \%$ majority for Mycoses belonged to infection in Udaipur [144]. Again in a desert region, In Bikaner, the husbandry animals are studied for the presence of bovine dermatophytes. They've confirmed the presence of hyperkeratosis, hyperplasia, disintegration and acanthosis of epidermis, spongiosis and leukocytic infiltration of dermis developed by $T$. verrucosum [145].

The Jaipur district (capital) is located towards North-eastern area on Aravalli Hills of the Rajasthan in Northern India. Jaipur has a semiarid climate receiving average daily temperatures of around $30^{\circ} \mathrm{C}$ and in the winter average temperatures ranging from $15^{\circ} \mathrm{C}-18^{\circ} \mathrm{C}$ and with humidity. The climate of Jaipur promotes to the growth of dermatophytes, which are best studied at Rajasthan University by several mycologist. Among them, D. Williamson and M. Sharma started to diagnose the Tinea in Jaipur region from 1984. In 1995, Iyer et al. 1995 started to diagnose the dermatophytic scenario of Jaipur at clinical level. Their team have been founded the surveillance of T. rubrum and T. mentagrophytes up to 62.19\%. Till 2008, Jain, Sharma and Saxena three dermatologists reviewed the dermatophytic infection in Jaipur. They are sampling from SMS hospital, Jaipur. In their results, T. rubrum was most predominant etiological agents in Jaipur citizens. T. schoenleinii (4.29\%) was firstly isolated in this study. In the sequence of it, in 2010-2013, several local mycologists have been updating the clinical dermatophytic status in Jaipur profile [146]-[151]. Specially In 2011-2012, isolation of Dermatophytic agents was isolated firstly among the HIV positives in Jaipur [152]. Clinical investigation of Ringworm infection relevant to animal and human health was conducted at the Department of Microbiology, Apollo College of Veterinary Medicine, Agra Road and Jaipur. The aim of the study was to assess the frequency of dermatophytes infection on the skin of dogs in and around the Jaipur city [153].

\section{Conclusion}

From the above collected review literature, it can be concluded that Earth has natural territory for fungi with the evolution. It covers forest, farmyard, park soils, and sediments of the rivers and oceans around the world. These all entire habituates contain humus and organic material which are best growth factors for keratinolytic and saprophytic fungi. In nature, fungi occurs as anamorphic and telomorphic states by which they cause the Mycoses. These fungi are presented in environment as Anthropophilic, Zoophilic, and Geophilic species. There are about 20 fungi, including dermatophytes, yeasts and non dermatophytes having the ability of degrading the keratin rich 
tissues. Infections by keratinolytic species are relatively common in developing countries due to wearing of dirty and pungent clothing, low socioeconomic status, crowded living conditions, a low tendency to self limitation, booming tourism, international sports activities, increasing migration and poor medical care which promotes to increase the epidemic spread of skin Mycoses. These dermatophytes are controlled by the utilization of compounds having molecular mass greater than 500 DA such as Amphotericin B (924.10 DA), Natamycin (665.75 DA) and Ketoconazole (531.44 DA), Amphotericin B and Miconazole. There is a possible prospect to search out new therapeutics as plants' remedies which generate natural drug against mycological disease.

\section{References}

[1] Sharma, A., Sharma, M. and Chandra, S. (2012) Influence of Temperature and Relative Humidity on Growth and Sporulation of Some Common Dermatophytes. Indian Journal of Fundamental and Applied Life Sciences, 2, 1-6.

[2] John, D.D. (1995) Superficial Fungal Infections of the Skin: Tinea corpris, Tinea pedis and Candida intertrigo. Elsevier Science, 2, 157-161.

[3] Batia, R. and Ichhpujani, R.L. (1994) Medical Mycology. In: Essentials of Medical Microbiology, Jaypee Brothers Medical Publishers, 635-674.

[4] Kwon-Chung, K.J., Edman, J.C. and Wickes, B.L. (1992) Genetic Association of Mating Types and Virulence in Cryptococcus neoformans. Infection and Immunity, 60, 602-605.

[5] Lacaz, C.S., Porto, A., Heins, V.A.T. and Melo, N.T. (1998) Guide to Identification of Fungi, Actinomycetes and Algae of Medical Interest. Sarvier.

[6] Monod, M., Jaccoud, S., Zaugg, C., Lechenn, B., Baudraz, F. and Panizzon, R. (2002) Survey of Dermatophyte Infections in the Lauseanne Area (Switzerland). Dermatology, 205, 201-203. http://dx.doi.org/10.1159/000063913

[7] Weitzman, I. and Summerbell, R.C. (1995) The Dermatophytes. Clinical Microbiology Reviews, 8, 240-259.

[8] Heinz, F.C. (1988) The Pathogenic Fungi. In: Medical Microbiology, 4th Edition, Mac Millun Publicting Co., NY, 341-347.

[9] Grover, W.C.S. and Roy, L.C.P. (2003) Clinico-Mycological Profile of Superficial Mycosis in a Hospital in North-East India. Medical Journal Armed Forces India, 59, 114-116. http://dx.doi.org/10.1016/S0377-1237(03)80053-9

[10] Havlickova, B., Viktor, A.C. and Markus, F. (2008) Epidemiological Trends in Skin Mycoses Worldwide. Mycoses, 51, 2-15. http://dx.doi.org/10.1111/j.1439-0507.2008.01606.x

[11] Ajello, L. and Getz, M.E. (1954) Recovery of Dermatophytes from Shoes and a Shower Stall. Journal of Investigative Dermatology, 22, 17-22. http://dx.doi.org/10.1038/jid.1954.5

[12] Chowdhry, P.N., Gupta, S.L. and Anand, N. (2013) Diversity of Fungi as Human Pathogen. Recent Research in Science and Technology, 5, 17-20.

[13] Rippon, J.W. (1982) Medical Mycology: The Pathogenic Fungi and the Pathogenic Actinomycetes. WB Saunders, London, 154-248.

[14] Simpanya, M.F. (2000) Dermayophytes: Their Taxonomy, Ecology and Pathogenicity. Revista Iberoamericana de Micologya, 1-12.

[15] Ajello, L., Georg, L.K., Kaplan, W. and Kaufman, L. (1966) Laboratory Manual for Medical Mycology. Communicable Disease Centre, Atlanta.

[16] Padhye, A.A. and Carmichael, J.W. (1971) The Genus Arthroderma berkeley. Canadian Journal of Botany, 49, 15251540. http://dx.doi.org/10.1139/b71-216

[17] Ajello, L. (1977) Taxonomy of the Dermatophytes: A Review of Their Imperfect and Perfect States. In: Recent Advances in Medical and Veterinary Mycology, University of Tokyo Press, Tokyo, 289-297.

[18] Stockdale, P.M. (1961) Nannizzia incurvata gen. Nov., sp. Nov., a Perfect State of Microsporum gypseum (Bodin). Sabouraudia, 1, 41-48. http://dx.doi.org/10.1080/00362176285190101

[19] Carris, L.M., Little, C.R. and Stiles, C.M. (2012) Introduction to Fungi. The Plant Health Instructor.

[20] Emmons, C.W. (1934) Dermatophytes. Natural Grouping Based on the Form of the Spores and Accessory Organs. Archives of Dermatology and Syphilology, 30, 337-362. http://dx.doi.org/10.1001/archderm.1934.01460150003001

[21] Ghannoum, M., Isham, N., Hajjeh, R., Cano, M., Hasawi, F., Yearick, D., Warner, J., Long, L., Jessup, C. and Elewski, B. (2003) Tinea capitis in Cleveland: Survey of Elementary School Students. Journal of the American Academy of Dermatology, 48, 189-193. http://dx.doi.org/10.1067/mjd.2003.109

[22] Weitzman, I., McGinnis, M.R., Padhye, A.A. and Ajello, L. (1986) The Genus Arthroderma and Its Later Synonym Nannizzia. Mycotaxon, 25, 505-518. 
[23] Ajello, L. (1968) A Taxonomic Review of Dermatophytes and Related Species. Sabouraudia, 6, 147-159. http://dx.doi.org/10.1080/00362176885190271

[24] Matsumoto, T. and Ajello, L. (1987) Current Taxonomic Concepts Pertaining to the Dermatophytes and Related Fungi. International Journal of Dermatology, 26, 491-499. http://dx.doi.org/10.1111/j.1365-4362.1987.tb02288.x

[25] Mucoma, F.S. (2000) Dermatophytes: Their Taxonomy, Ecology and Pathogenicity. Department of Biological Sciences, University of Botsuana, Gaborone, 1-10.

[26] Gotz, H. (1964) Remarks on the Classification of Dermatophytes. Annales de la Societe Belge de Medecine Tropicale, 44, 693-702.

[27] Ali, J., Yifru, S. and Woldeamanuel, Y. (2009) Prevalence of Tinea capitis and the Causative Agent among School Children in Gondar, North West Ethiopia. Ethiopian Medical Journal, 47, 261-269.

[28] Hussain, A.I., Efstratiou, E., Moore, J.E., Singh, N.N. and Rao, P. (2012) Anti Microbial Activity of Callendula officinalis Petal Extracts against Fungi, as Well as Gram-Negative and Gram-Positive Clinical Pathogens. Complementary Therapies in Clinical Practice.

[29] Mackenzie, D.W.R. and Philpot, C.M. (1981) Isolation and Identification of Ringworm Fungi. Public Health Laboratory Service, Monograph Series, 15, 1-59.

[30] Ajello, L. (1974) Natural History of the Dermatophytes and Related Fungi. Mycopathologia et Mycologia Applicata, 53, 93-110. http://dx.doi.org/10.1007/BF02127200

[31] Gileno, A.A., Antonio, A.X., Leonildo, B.G., Bento, G., Davi, R., Rodolfo, M., Gileno, C. and Rinaldo, A. (2008) Dermatophytosis Caused by Microsporum canis and Microsporum gypsum in Free Living Bradypus variegates in the State of Pernambuco, Brazil. Brazilian Journal of Microbiology, 39, 508-510. http://dx.doi.org/10.1590/S1517-83822008000300018

[32] Lakshmipathy, D.T. and Kannabiran, K. (2010) Review on Dermatomycosis: Pathogenesis and Treatment. Natural Science, 2, 726-731. http://dx.doi.org/10.4236/ns.2010.27090

[33] Maraki, S., Nioti, E. and Mantadakis, E. (2007) A 7-Year Survey of Dermatophytoses in Crete Greece. Mycoses, 50, 481-484. http://dx.doi.org/10.1111/j.1439-0507.2007.01403.x

[34] Georg, L.K. (1959) Animals Ringworm in Public Health. Diagnosis and Nature, Bulletin, 57.

[35] Achterman, R.R., Smith, A.R., Oliver, B.G. and White, T.C. (2011) Sequenced Dermatophyte Strains: Growth Rate, Conidiation, Drug Susceptibilities, and Virulence in an Invertebrate Model. Fungal Genetics and Biology, 48, 335-341. http://dx.doi.org/10.1016/j.fgb.2010.11.010

[36] Nweze, E. (2010) Dermatophytosis in Western Africa: A Review. Pakistan Journal of Biological Sciences, 13, 649656. http://dx.doi.org/10.3923/pjbs.2010.649.656

[37] Philpot, C.M. (1977) Some Aspects of the Epidemiology of Tinea. Mycopathologia, 62, 3-13. http://dx.doi.org/10.1007/BF00491990

[38] Silva, D.P.Z.B. and Oliveira, A.C. (2008) Dermatophytes from Urban Soils in Joao Pessoa, Paraíba, Brazil. Revista Argentina de Microbiología, 40, 161-163.

[39] Mikaili, A., Chalabi, M. and Ghashghaie, A. (2012) Immunization against Bovine Dermatophytosis with Live Trichophyton verrucosum. African Journal of Microbiology Research, 6, 4950-4953.

[40] Farzana, A.N. (2007) Prevalence and Etiology of Dermatomycoses in Rajshahi, Bangladesh. Journal of Life and Earth Science, 2, 75-78.

[41] Georg, L.K. (1960) Epidemiology of Dermatophytes Sources of Infection, Modes of Transmission and Epidemicity. Annals of the New York Academy of Sciences, 89, 69-77.

[42] Kaplan, W. and Gump, R.H. (1958) Ringworm in the Dog Caused by Trichophyton rubrum. Veterinary Medicine, 53, 139-142.

[43] English, M.P. (1972) The Epidemiology of Animal Ringworm in Man. British Journal of Dermatology, 86, 78-87.

[44] Achterman, R.R. and White, T.C. (2012) Dermatophyte Virulence Factors: Identifying and Analyzing Genes That May Contribute to Chronic or Acute Skin Infections. International Journal of Microbiology, 2012, 1-8. http://dx.doi.org/10.1155/2012/358305

[45] Jahromi, S.B. (2013) Epidemiological Trends in Zoophilic and Geophilic Fungi in Iran. British Association of Dermatologists. Clinical and Experimental Dermatology, 38, 13-19. http://dx.doi.org/10.1111/j.1365-2230.2012.04462.x

[46] Spiewak, R. and Szostak, W. (2000) Zoophilic and Geophilic Dermatophytoses among Farmers and Non-Farmers in Eastern Poland. Annals of Agricultural and Environmental Medicine, 7, 125-129.

[47] Ajello, L. (1961) Present Day Concepts of the Dermatophytes. Invited Paper, Annual Meeting of the American Academy of Dermatology, Chicago. 
[48] Marples, M.J. (1956) The Ecology of Microsporum canis Bodin in New Zealand. Journal of Hygiene, 54, 378-387. http://dx.doi.org/10.1017/S0022172400044636

[49] Idnurm, A., Bahn, Y.S. and Nelsen, K. (2005) Deciphering the Model Pathogenic Fungus Cryptococcus neoformans. Nature Reviews Microbiology, 3, 53-64.

[50] Bohme, H. and Ziegler, H. (1969) The Distribution of Geophilic Dermatophytes and Other Keratinophilic Fungi in Relation to the $\mathrm{pH}$ of the Soil. Mycopathologia et Mycologia Applicata, 38, 247-255.

[51] Lin, X., Lee, C. and Casale, S. (1992) Purification and Characterization of a Keratinase from a Feather Degrading Bacillus licheniformis Strain. Applied and Environmental Microbiology, 58, 3271-3275.

[52] Sharma, R. and Swati (2012) Effect of Keratin Substrates on the Growth of Keratinophilic Fungi. Journal of Academia and Industrial Research, 1, 170-172.

[53] Kunert, J. (2000) Physiology of Keratinophilic Fungi. In: Kushwaha, R. and Guarro, J., Eds., Biology of Dermatophytes and Other Keratinophilic Fungi, Revista Iberoamericana de Micologia, Bilbao, 77-85.

[54] Friedrich, A.B. and Antranikian, G. (1996) Keratin Degradation by Fervidobacterium pennavorans, a Novel Thermophilic Anaerobic Species of the Order Thermotogales. Applied and Environmental Microbiology, 62, 2875-2882.

[55] Rippon, J.W. (1974) Medical Mycology: The Pathogenic Fungi and the Pathogenic Actinomycetes. W.B. Saunders Co., Philadelphia, $842 \mathrm{p}$.

[56] Yu, R.J., Harmon, S.R. and Blank, F. (1969) Hair Digestion by a Keratinase of Trichophyton mentagrophytes. Journal of Investigative Dermatology, 53, 166-171.

[57] Grappel, S.F., Bishop, C.T. and Blank, F. (1974) Immunology of Dermatophytes and Dermatophytosis. Bacteriological Reviews, 38, 222-250.

[58] Grappel, F. (1976) Role of Keratinases in Dermatophytosis. Dermatology, 153, 157-162. http://dx.doi.org/10.1159/000251110

[59] Sandy, V. (2008) Pathogenesis of Dermatophytosis. Mycopathologia, 166, 267-275. http://dx.doi.org/10.1007/s11046-008-9104-5

[60] Richardson, M.D., Aljabre, S.H., Scott, E.M., Rashid, A. and Shankland, G.S. (1993) Adherence of Arthroconidia and Germlings of Anthropophilic and Zoophilic Varieties of Trichophyton mentagrophytes to Human Corneocytes as an Early Event in the Pathogenesis of Dermatophytosis. Clinical and Experimental Dermatology, 18, 231-235. http://dx.doi.org/10.1111/j.1365-2230.1993.tb02176.x

[61] Dahl, M.V. (1993) Suppression of Immunity and Inflammation by Products Produced by Dermatophytes. Journal of the American Academy of Dermatology, 28, 19-23.

[62] Wagner, D.K. and Sohnle, P.G. (1995) Cutaneous Defenses against Dermatophytes and Yeasts. Clinical Microbiology Reviews, 8, 317-355.

[63] Chander, J. (1995) Dermatophytoses. Textbook of Medical Mycology, 91-112.

[64] Mahmoudabadi, A.Z., Zarrin, M. and Mehdinezhad, F. (2013) Seborrheic Dermatitis Due to Malassezia Species in Ahvaz, Iran. Iranian Journal of Microbiology, 5, 268-271.

[65] Picrard, G.E. (1996) Treatment and Prophylaxis of Time Infections. Drugs, 52, 208-224.

[66] Shamim, S., Ahmed, S.W., Siddiqui, S.A. and Azhar, I. (2005) Superficial Mycoses: A Study Performed For the Isolation and Identification of Fungal Species from Infected Patients. Pakistan Journal of Pharmacology, 22, 41-46.

[67] Smith, E.S., Feldman, S.R., Fleischer, A.B., Leshin, B. and Mcmichael, A. (1998) Characteristics of Office-Based Visits for Skin Cancer: Dermatologists Have More Experience Than Other Physicians in Managing Malignant and Premalignant Skin Conditions. Dermatologic Surgery, 24, 981-985. http://dx.doi.org/10.1111/j.1524-4725.1998.tb04291.x

[68] Mihali, C.V., Buruiana, A. and Turcus, V. (2012) Comparative Studies of Morphology and Ultra Structure in Two Common Species of Dermatophytes: Microsporum canis and Microsporum gypseum. Annals of RSCB, 17, 85-89.

[69] Laham, N.A., Abdelateef, N. and Naieem, M. (2011) Dermatophytosis among Outpatients in Gaza, Particularly Tinea capitis. Journal of Al Azhar University-Gaza (Natural Sciences), 13, 17-30.

[70] Gavela, E., Avila, A., Sancho, A., Molina, P., Najera, J.E.F., Crespo, J. and Pallardo, L.M. (2006) Chronological Aggregation of Subcutaneous Mycosis in Renal Transplant Recipients. Nephrology Department. Nefrología, 26, 476-480.

[71] Degreef, H.J. and Dedoncker, P.R.G. (1944) Current Therapy of Dermatophytosis. Journal of the American Academy of Dermatology, 31, 525-530.

[72] Dekate, S., Padhye, S. and Gautam, A. (2011) Identification \& Characterization of Fungi Causing Superficial Mycoses. International Journal of Pharmaceutical and Life Sciences, 2, 782-786.

[73] Mishara, S.K. and Sandhu, R.S. (1972) Deep Mycoses in India. Mycopathologia et Mycologia Applicata, 48, $339-365$. http://dx.doi.org/10.1007/BF02052638 
[74] Hapcioglu, B., Yegenoglu, Y., Disci, R., Erturan, Z. and Kaymakcalan, H. (2006) Epidemiology of Superficial Mycosis (Tinea Pedis, Onychomycosis) in Elementary School Children in Istanbul, Turkey. Collegium Antropologicum, 30, 119-124.

[75] Mahmoudabadi, A.Z. (2005) A Study of Dermatophytosis in South West of Iran (Ahwaz). Mycopathologia, 160, 21-24. http://dx.doi.org/10.1007/s11046-005-7458-5

[76] Khaksari, A.A. and Bassiri, J.S. (2009) Epidemiological Survey of Dermatophytosis in Tehran, Iran, from 2000 to 2005. Indian Journal of Dermatology, Venereology and Leprology, 75, 142-147. http://dx.doi.org/10.4103/0378-6323.48658

[77] Jahangir, M., Hussain, I., Khurshid, K. and Haroon, T.S. (1999) A Clinico-Etiologic Correlation in Tinea capitis. International Journal of Dermatology, 38, 275-278. http://dx.doi.org/10.1046/j.1365-4362.1999.00652.x

[78] Daniel, H.L. (2010) The Barefoot Book: 50 Great Reasons to Kick off Your Shoes. Hunter House, Alameda.

[79] Rapini, R.P., Bolognia, J.L. and Jorizzo, J.L. (2007) Dermatology. Vol. 2, Mosby, St. Louis.

[80] Harvey, A. and Stoppler, M.C. (2011) Fungal Nails (Onychomycosis, Tinea unguium). www.Medicinenet.com

[81] Burzykowski, T., Molenberghs, G. and Abeck, D. (2003) High Prevalence of Foot Diseases in Europe: Results of the Achilles Project. Mycoses, 46, 496-505. http://dx.doi.org/10.1046/j.0933-7407.2003.00933.x

[82] Verma, S. and Heffernan, M. (2008) Superficial Fungal Infection: Dermatophytosis, Onychomycosis, Tinea Nigra, T. Piedra. In: Fitzpatrick’s Dermatology in General Medicine, 7th Edition, Vol. 2, McGraw Hill, New York, 1807-1821.

[83] James, W.D. and Berger, T.G. (2006) Andrews Diseases of the Skin: Clinical Dermatology. Saunders Elsevier, Philadelphia.

[84] Weston, W.L. (2010) Overview of Dermatitis. http://www.uptodate.com

[85] Abbas, A.K., Mohammed, Z.A. and Mahmoud, I.S. (2012) Superficial Fungal Infections. Mustansiriya Medical Journal, 11, 75-77.

[86] Bitar, A. (1973) Superficial Mycosis. Canadian Family Physician (Maritime Chapters College of Family Physicians of Canada), 65-68.

[87] Hay, R.J., Campbell, C.K., Wingfield, R. and Clayton, Y.M. (1983) A Comparative Study of Dermatophytosis in Coal Miners and Dermatological Outpatients. British Journal of Industrial Medicine, 40, 353-355.

[88] Brown, M.R., Thompson, C.A. and Mohamed, F.M. (2005) Systemic Candidiasis in an Apparently Immunocompetent Dog. Journal of Veterinary Diagnostic Investigation, 17, 272-276. http://dx.doi.org/10.1177/104063870501700312

[89] Kuwamura, M., Ide, M., Yamate, J., Shiraishi, Y. and Kotani, T. (2006) Systemic Candidiasis in a Dog Developing Spondylitis. Journal of Veterinary Medical Science, 68, 1117-1119. http://dx.doi.org/10.1292/jvms.68.1117

[90] Kazemi, A. (2013) An Overview on the Global Frequency of Superficial/Cutaneous Mycoses and Deep Mycoses. Jundishapur Journal of Microbiology, 6, 202-204.

[91] Skoric, M., Fictum, P., Slana, I., Kriz, P. and Pavlik, I. (2011) A Case of Systemic Mycosis in a Hovawart Dog Due to Candida albicans. Veterinarni Medicina, 56, 260-264.

[92] Heseltine, J.C., Panciera, D.L. and Saunders, G.K. (2003) Systemic Candidiasis in a Dog. Journal of the American Veterinary Medical Association, 223, 821-824. http://dx.doi.org/10.2460/javma.2003.223.821

[93] Koga, T., Matsuda, T., Matsumoto, T. and Masutak, I. (2003) Thereputic Approaches to Subcautenious Mycoses. American Journal of Clinical Dermatology, 4, 437-438.

[94] Mackinnon, J.E. (1969) Isolation of Sporothrix schenckii from Nature and Considerations on Its Pathogenicity and Ecology. Sabouraudia, 7, 38-45. http://dx.doi.org/10.1080/00362177085190071

[95] Grover, S. and Seeveri, R. (1970) Rhinosporidium seeberi; a Preliminary Study of the Morphology and Life Cycle. Sabouraudia, 7, 249-251. http://dx.doi.org/10.1080/00362177085190451

[96] Dixon, D.M. (1980) Dematiaceous Fungal Pathogens Isolated from Nature. Mycopathologia, 70, $153-161$. http://dx.doi.org/10.1007/BF00443026

[97] Gautam, K., Rao, P.B. and Chauhan, S.V.S. (2003) Antifungal Potency of Some Species of Family Asteraceae (Compositae) against Macrophomina phaseolina (Tassi) Goid. Journal of Mycology and Plant Pathology, 33, $294-295$.

[98] Bulmer, G.S. and Fromtling, R.A. (1983) Pathogenic Mechanisms of Mycotic Agents in Fungi Pathogenic for Humans and Animals. 2nd Edition, New York.

[99] Razzuk, M.A., Harold, C., Urschel, J. and Paulson, D.L. (1973) Systemic Mycoses—Primary Pathogenic Fungi. Collective Review: Systemic Mycoses. Annals of Thoracic Surgery, 15, 644-660. http://dx.doi.org/10.1016/S0003-4975(10)65361-1

[100] Randhawa, H.S. (2000) Respiratory and Systemic Mycoses: An Overview. Indian Journal of Chest Disease and Allied Science, 42, 207-219. 
[101] Ortiz, A.M.P., Gonzalez, D.V. and Bonifaz, A. (2012) Opportunistic Filamentous Mycoses: Aspergillosis, Mucormycosis, Phaeohyhomycosis and Hyalohyphomycosis. Journal of the German Society of Dermatology-JDDG, 9, 611621.

[102] Waurzyniak, B.J., Hover, J.P., Clinkenbeard, K.D. and Welsh, R.D. (1992) Dual Systemic Mycosis Caused by Bipolaris spicifera and Torulopsis glabrata in a Dog. Veterinary Pathology, 6, 566-569. http://dx.doi.org/10.1177/030098589202900620

[103] Ascioglu, S., Rex, J.H., Pauw, B., Bennett, J.E., Bille, J., Crokaert, F., Denning, D.W., Donnelly, J.P., Edwards, J.E., Erjavec, Z., Fiere, D., Maertens, J., Meis, J.F., Patterson, T.F., Ritter, J., Selleslag, D., Shah, P.M., Stevens, D.A. and Walsh, T.J. (2002) Defining Opportunistic Invasive Fungal Infections in Immune Compromised Patients with Cancer and Hematopoietic Stem Cell Transplants: An International Consensus. Clinical Infectious Diseases, 34, 7-14. http://dx.doi.org/10.1086/323335

[104] Calvo, A., Vidal, M. and Guarro, J. (1984) Keratinophilic Fungi from Urban Soils of Barcelona, Spain. Mycopathologia, 85, 145-147.

[105] Caretta, G. and Piontelli, E. (1975) Isolation of Keratinophilic Fungi from Soil in Pavia, Italy. Sabouraudia, 3, 33-37. http://dx.doi.org/10.1080/00362177585190061

[106] Caretta, G., Frat, G., Piontelli, E. and Todaro, F. (1977) Distribution of Keratinophilic Fungi in the Soil of Volcano Etna (Sicily). Rivista di Parassitologia, 38, 115-127.

[107] Crozier, W.J. (1980) The Prevalence of Geophilic Dermatophytes in Soils of Illawarra Area of New South Wales. Australasian Journal of Dermatology, 21, 89-95. http://dx.doi.org/10.1111/j.1440-0960.1980.tb00149.x

[108] Iyer, S.R., Bhargava, R., Sharma, M. and Williamson, D. (1995) Dermatophytic Profile of Jaipur (Rajasthan). Ancient Science of Life, 14, 181-186.

[109] Ellabib, M.S. and Khalifa, Z.M. (2001) Dermatophytes and Other Fungi Associated with Skin Mycoses in Tripoli, Libya. Annals of Saudi Medicine, 21, 193-195.

[110] Ndako, J.A., Osemwegie, O.O., Spencer, T.H., Olopade, B.K., Yunusa, G.A. and Banda, J. (2012) Prevalence of Dermatophytes and Other Associated Fungi among School Children. Global Advanced Research Journal of Medicine and Medical Sciences, 1, 49-56.

[111] Rizwana, H., Hazzani, A.A.A. and Siddiqui, I. (2012) Prevalence of Dermatophytes and Other Keratinophilic Fungi from Soils of Public Parks and Playgrounds of Riyadh. The Journal of Animal \& Plant Science, 22, 948-953.

[112] Kim, J.D. (2003) Keratinolytic Activity of Five Aspergillus Species Isolated from Poultry Farming Soil in Korea. Mycobiology, 31, 157-161. http://dx.doi.org/10.4489/MYCO.2003.31.3.157

[113] Rhee, D.Y., Kim, M.S. and Chang, S.E. (2009) A Case of Tinea Manuum Caused by Trichophyton mentagrophytes var. erinacei: The First Isolation in Korea. Mycoses, 52, 287-290. http://dx.doi.org/10.1111/j.1439-0507.2008.01556.x

[114] Olivares, R.A.C., Chavez, R.E.G., Zaragoza, C.S. and Perez, G.T. (2000) Presence of Keratinophilic Fungi with Special Reference to Dermatophytes on the Haircoat of Dogs and Cats in Mexico and Nezahualcoyotl Cities. Revista Latinoamericana de Microbiología, 42, 41-44.

[115] Parvin, R., Amin, R., Mahbub, S., Hasnain, M., Mohammad, A.K., Titu, M., Gupta, R.D., Alam, B. and Ahasan, H.N. (2010) Deep Fungal Infection-An Emerging Problem in Bangladesh. Journal of Medicine, 11, 170-175. http://dx.doi.org/10.3329/jom.v11i2.5466

[116] Neela, F.A. and Shah, A. (2000) A Survey on Tinea Disease in Rajshahi, Bangladesh. University Journal of Zoology, Rajshahi University, 19, 73-77.

[117] Asadi, M.A., Dehghani, R. and Sharif, M.R. (2009) Epidemiologic Study of Onychomycosis and Tinea Pedis in Kashan, Iran. Jundishapur Journal of Microbiology, 2, 61-64.

[118] Mahmoudabadi, A.Z. and Zarrin M. (2008) Isolation of Dermatophytes and Related Keratinophilic Fungi from the Two Public Parks in Ahvaz. Jundishapur Journal of Microbiology, 1, 20-23.

[119] Dehghan, M., Hajian, S., Alborzi, N., Borgheyee, A. and Noohi, A.H. (2009) Clinico-Mycological Profiles of Dermatophytosis in Gorgan, North of Iran. Iranian Journal of Dermatology, 12, 13-15.

[120] Ghahfarokhi, S.M., Tehrani, M.F., Bahadori, R.S. and Abyaneh, R.M. (2009) An Epidemiological Survey on Cattle Ringworm in Major Dairy Farms of Mashhad City, Eastern Iran. Iranian Journal of Dermatology, 1, 31-36.

[121] Irum, F., Suhail, M. and Abro, H. (2007) Keratinophilic Fungi from the Soil of District, Jamshoro and Sindh, Pakistan. Pakistan Journal of Botany, 39, 1377-1382.

[122] Thebo, N.K., Abro, H., Soomro, A.Q., Anwer, J. and Suhail, M. (2006) Isolation and Identification of Dermatophytes from Sindh, Pakistan. Pakistan Journal of Botany, 38, 493-495.

[123] Prakash, B., Kumar, S., Rao, M.S. and Giri, S.C. (2000) Holocene Tectonic Movements and Stress Field in the Western Gangetic Plains. Current Science, 79, 438-449. 
[124] Singh, S. and Beena, P.M. (2003) Comparative Study of Different Microscopic Techniques and Culture Media for the Isolation of Dermatophytes. Indian Journal of Medical Microbiology, 21, 21-24.

[125] Philpot, C.M. (1978) Serological Differences among the Dermatophytes. Sabouraudia, 16, 247-256. http://dx.doi.org/10.1080/00362177885380351

[126] Thirumalachar, M.I. (1968) Saprophytic Habitats of Causative Agent of Human Mycoses in India. SL Hora Memorial Lecture, 35, 113-124.

[127] Deshmukh, S.K. and Verekar, S.A. (2006) The Occurrence of Dermatophytes and Other Keratinophilic Fungi from the Soils of Himachal Pradesh (India). Czech Mycology, 58, 117-124.

[128] Puri, A. and Puri, N. (2013) A Study on Tinea capitis in the Preschool and School Going Children. Our Dermatology Online, 4, 157-160. http://dx.doi.org/10.7241/ourd.20132.36

[129] Chaturvedi, S., Pathak, S., Upadhyay, R. and Dubey, S. (2013) Comparative Study of Dermatophytic Fungi for Extra Cellular Proteases Efficacy. Research \& Reviews: Journal of Microbiology and Biotechnology, 2, 66-77.

[130] Kumar, R., Mishra, R., Maurya, S. and Sahu, H.B. (2012) Prevalence of Keratinophilic Fungi in Piggery Soils of Jharkhand, India. The ECOSCAN: An International Quarterly Journal of Environmental Sciences, 1, 93-98.

[131] Kundu, D., Mandal, L. and Sen, G. (2012) Prevalence of Tinea capitis in School Going Children in Kolkata, West Bengal. Journal of Natural Science, Biology and Medicine, 3, 152-155. http://dx.doi.org/10.4103/0976-9668.101894

[132] Balakumar, S., Rajan, S., Thirunalasundari, T. and Jeeva, S. (2012) Epidemiology of Dermatophytosis in and around Tiruchirapalli, Tamilnadu, India. Asian Pacific Journal of Tropical Disease, 2, 286-289. http://dx.doi.org/10.1016/S2222-1808(12)60062-0

[133] Doddamani, P.V., Harshan, K.H., Kanta, R.C., Gangane, R. and Sunil, K.B. (2013) Isolation, Identification and Prevelance of Dermatophytes in Tertairy Care Hospital in Gulbarga District. People's Journal of Scientific Research, 6, 10-13.

[134] Sajjan, A.G. and Mangalgi, S.S. (2012) Clinicomycological Profile of Tinea capitis in Children Residing in Orphanages. International Journal of Biological \& Medical Research, 3, 2405-2407.

[135] Rai, M.K. and Shrivastava, K.K. (1992) On the Incidence of Raktaja Krimi (Dermatophytes) in Chhindwara, Madhya Pradesh. Ancient Science of Life, 12, 221-226.

[136] Pal, M. (1995) Prevalence in India of Dermatophilus congolensis Infection in Clinical Specimens from Animals and Humans. Revue Scientifique et Technique (International Office of Epizootics), 14, 857-863.

[137] Singh, S. and Beena, P.M. (2003) Profile of Dermatophytes Infections in Baroda. Indian Journal of Dermatology, Venereology and Leprology, 69, 281-283.

[138] Bhavsar, H.K., Modi, D.J., Sood, N.K. and Shah, H.S. (2012) A Study of Superficial Mycoses with Clinical Mycological Profile in Tertiary Care Hospital in Ahmadabad, Gujarat. National Journal of Medical Research, 2, 160-164.

[139] Deshmukh, S.K. and Verekar, S.A. (2012) Prevalence of Keratinophilic Fungi in Public Park Soils of Mumbai, India. Microbiology Research, 3, 24-27.

[140] Naruka, H.S. and Chand, A.E. (2013) Prevalence of Onychomycosis in South East Part of Rajasthan. Journal of Evolution of Medical and Dental Sciences, 2, 500-505. http://dx.doi.org/10.14260/jemds/294

[141] Karmakar, S., Kalla, G., Joshi, K.R. and Karmakar, S. (1995) Dermatophytosis in a Desert District of Western Rajasthan. Indian Journal of Dermatology, Venereology and Leprology, 61, 280-283.

[142] Balai, M., Khare, A.A.K., Gupta, L.K., Mittal, A. and Kuldeep, C.M. (2012) Pattern of Pediatric Dermatoserina Tertiary Care Centre of South West Rajasthan. Indian Journal of Dermatology, 57, 275-278. http://dx.doi.org/10.4103/0019-5154.97665

[143] Singh, N., Yadav, J.S., Singh, A.P. and Sharma, S.N. (1997) Clinico-Epidemiological Studies on Bovine Dermatophytosis in and around Bikaner. Indian Journal of Animal Sciences, 68, 845-848.

[144] Jain, N., Sharma, M. and Saxena, V.N. (2008) Clinico-Mycological Profile of Dermatophytosis in Jaipur Rajasthan. Indian Journal of Dermatology, Venereology and Leprology, 74, 274-275. http://dx.doi.org/10.4103/0378-6323.41388

[145] Sharma, M. and Sharma, M. (2010) Incidence of Dermatophytes and Other Keratinophilic Fungi in the Schools and College Playground Soils of Jaipur, India. African Journal of Microbiology Research, 4, 2647-2654.

[146] Sharma, R., Sharma, R., Sharma, M. and Sharma, G. (2012) Studies on the Mycoflora Associated with Sewage Water in Bagru and Jharna Area (Rajasthan). African Journal of Microbiology Research, 6, 6748-6754.

[147] Sharma, M., Sharma, M. and Rao, V.M. (2011) In Vitro Biodegradation of Keratin by Dermatophytes and Some Soil Keratinophiles. African Journal of Biochemistry Research, 5, 1-6.

[148] Sharma, M. and Sharma, R. (2012) Profile of Dermatophytic and Other Fungal Infections in Jaipur. Indian Journal of Microbiology, 52, 270-274. http://dx.doi.org/10.1007/s12088-011-0217-z 
[149] Jasuja, N.D., Sharma, R. and Sharma, S. (2012) Clinical and Mycological Study of Dermatophytosis in Jaipur (India). International Journal of Pharmacy and Pharmaceutical Sciences, 4.

[150] Jain, N. and Sharma, M. (2012) Biodiversity of Keratinophilic Fungal Flora in University Campus, Jaipur, India. Iranian Journal of Public Health, 41, 27-33.

[151] Bhadauria, S. and Kumar, P. (2012) Broad Spectrum Antidermatophytic Drug for Control of Tinea Infection in Human Beings. Mycoses, 55, 339-343. http://dx.doi.org/10.1111/j.1439-0507.2011.02120.x

[152] Sharma, S.K., Sharma, P. and Agrawal, R.D. (2011) Effect of Temperature and pH Combinations on Growth Pattern of Dermatophytes Isolated from HIV Positive Patients. Asian Journal of Biochemical and Pharmaceutical Research, 3, 307-312.

[153] Gangil, R., Dutta, P., Tripathi, R., This, R.S. and Lakhotia, R.L. (2012) Incidence of Dermatophytosis in Canine Cases Presented at Apollo Veterinary College, Rajashtan, India. Veterinary World, 5, 682-684.

http://dx.doi.org/10.5455/vetworld.2012.682-684 
Scientific Research Publishing (SCIRP) is one of the largest Open Access journal publishers. It is currently publishing more than 200 open access, online, peer-reviewed journals covering a wide range of academic disciplines. SCIRP serves the worldwide academic communities and contributes to the progress and application of science with its publication.

Other selected journals from SCIRP are listed as below. Submit your manuscript to us via either submit@scirp.org or Online Submission Portal.
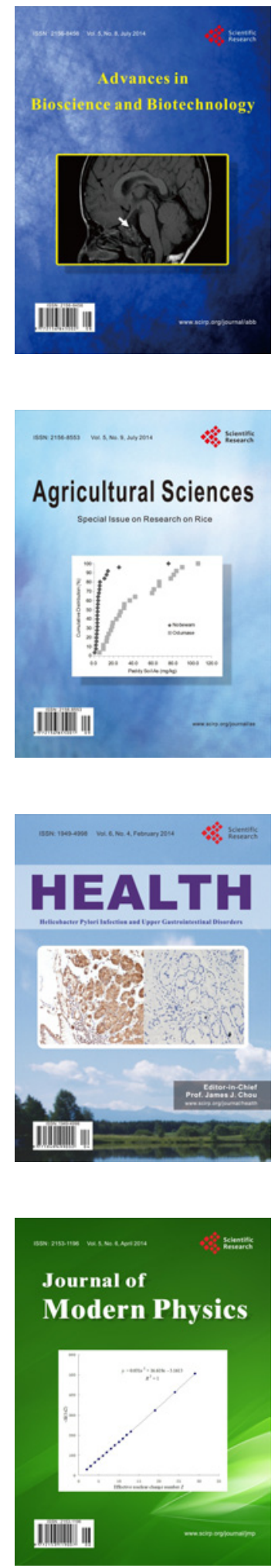
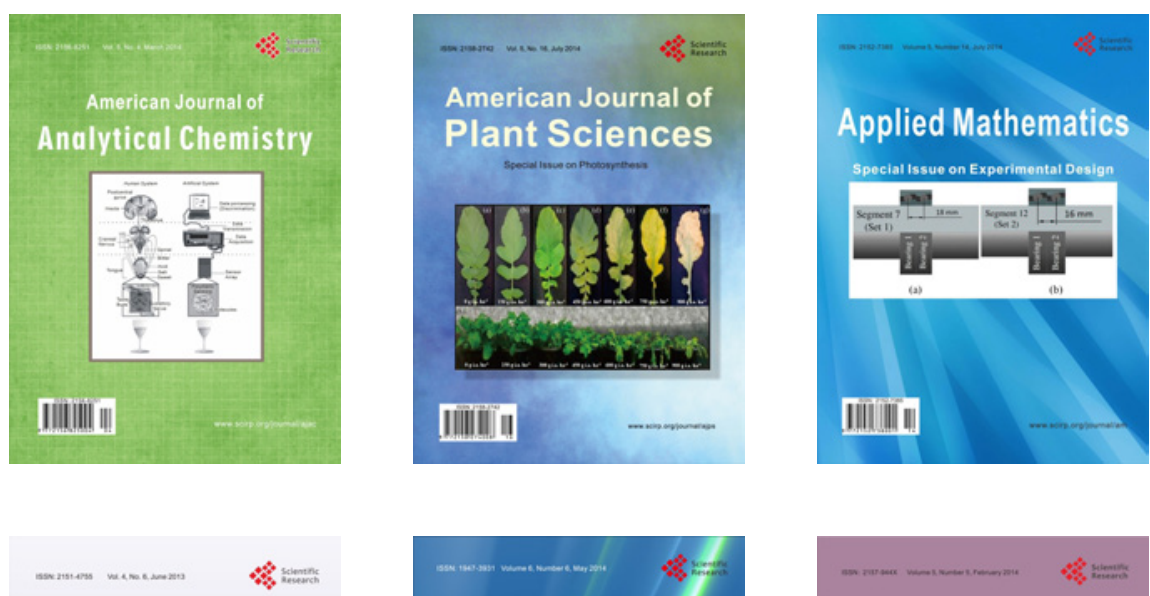

Creative Education
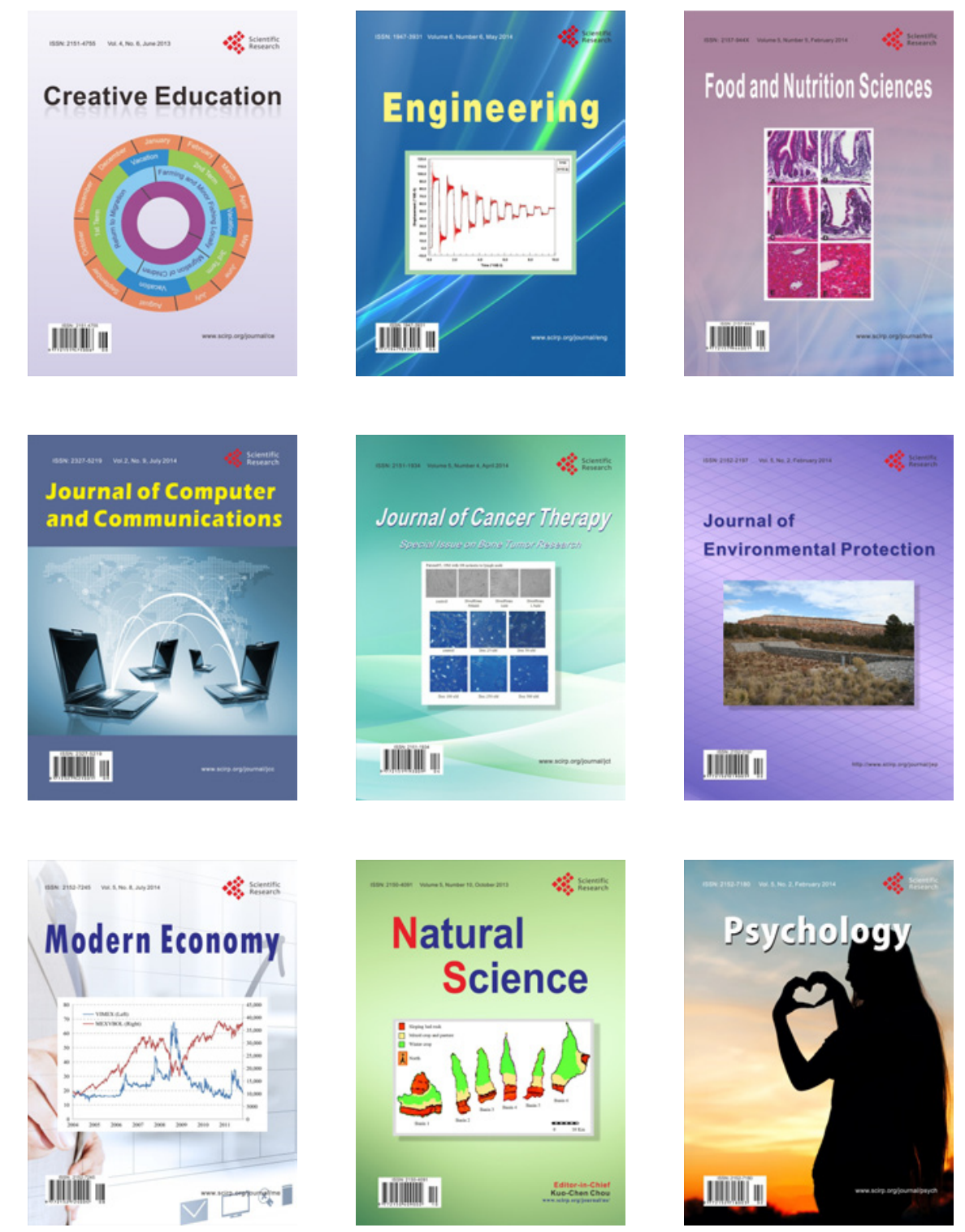